\title{
The mental health of prisoners
}

\section{Luke Birmingham}

\begin{abstract}
Mental health problems are the most significant cause of morbidity in prisons. Over $90 \%$ of prisoners have a mental disorder. The prison environment and the rules and regimes governing daily life inside prison can be seriously detrimental to mental health. Prisoners have received very poor health care and, until recently, the National Health Service (NHS) had no obligations to service this group, which was the Home Office's responsibility. The NHS is expected to take responsibility eventually, following a new health partnership with the Prison Service. NHS psychiatrists will have to be much more active in the development and delivery of health care to prisoners who now have the right to equal health care. There are positive developments but concerted and determined action is required to bring prison health care up to acceptable standards.
\end{abstract}

Until very recently, responsibility for providing health care in prisons rested solely with the Prison Service, and the standard of health care delivered by the Prison Health Service (formerly known as the Prison Medical Service) was criticised repeatedly (Smith, 1999). Calls for the National Health Service (NHS) to take over responsibility for health care in prisons began almost immediately after it came into being in 1948. But during the first 50 years of its existence, the NHS, the statutory provider of health care to everyone else in England, Wales, Scotland and Northern Ireland, was not obliged to consider the needs of anyone detained in prison.

In 1996, the Chief Inspector of Prisons produced a report entitled Patient or Prisoner? (Her Majesty's Inspectorate of Prisons, 1996). This highlighted weaknesses in prison health care services, particularly in relation to the quality of care provided for prisoners, professional isolation of prison health care staff and poor links with the NHS. The report recommended that the NHS should take over responsibility for prison health care and it outlined several ways in which this could be achieved.

The following year, the Health Advisory Committee for the Prison Service published its report The Provision of Mental Health Care in Prisons (Health Advisory Committee for the Prison Service, 1997). This drew attention to the poorly coordinated delivery of health care in prisons and the need for more effective throughcare and aftercare arrangements. The Committee promoted the concept of equivalence of care (Box 1).

The next step in the reform process was a groundbreaking initiative involving the establishment of a joint Prison Service and NHS Executive working group to address the issues raised in Patient or Prisoner? and The Provision of Mental Health Care in Prisons and develop practical proposals for change that would enable prisoners to be provided with a level of health care equivalent to that for the general population. The report of this working group, published in March 1999, embraced the concept of equivalence and set out proposals for major reform, including the creation of a formal partnership between the Prison Service and the NHS (Prison Service \& NHS Executive Working Group, 1999). The working group's recommendations were accepted by the Government and, in April 2000, the former Directorate of Health Care for Prisons, situated at the Home Office, was replaced by the Prison Health Policy Unit and the Prison Task Force, located in the Department of Health. Further information on the Health Policy Unit and Task Force and the ongoing developments in prison health care can be found on the Department of Health's website (http://www. doh.gov.uk/prisonhealth). Until recently, prison health care was delivered by a partnership between the Prison Service and the NHS, but on 1 April 2003, funding responsibility for prison health services in

\section{Box 1 Equivalence of care}

A report by the Health Advisory Committee for the Prison Service (1997) states that prisons should 'give prisoners access to the same quality and range of health care services as the general public receives from the NHS.'

Luke Birmingham is a senior lecturer at the University of Southampton and an honorary consultant in forensic psychiatry at Ravenswood House Medium Secure Unit (Knowle, Fareham, Hampshire PO17 5NA, UK). His research interests include prison mental health care and mentally disordered offenders, and he has acted as a guest medical inspector for Her Majesty's Prison Inspectorate. 
England was transferred from the Home Office to the Department of Health. This was the first step in a process which will see prison health become part of the NHS over the next 5 years. In addition, over the next 3 years, additional resources are to be allocated by the Department of Health, rising to an extra $£ 46$ million a year by 2005-2006.

Mental health problems are by far the most significant cause of morbidity in prisons, and prisoners with mental disorders create a major challenge for the Prison Service. The new health partnership means that responsibility for providing care is now shared with the NHS. Because Government policy for health care now applies equally to prisoners, NHS psychiatrists (among others) will be required to play a much more active role in the development and delivery of health care to people in prison.

This article deals primarily with issues relating to the mental health of prisoners in England and Wales. It begins with a brief overview of the prison population and then examines the levels of psychiatric disorder, substance misuse, self-harm and suicide found among prisoners. Because the mental health of prisoners concerns much more than just the prevalence of psychiatric morbidity in the prison population, the second half of this article concentrates on imprisonment and mental health, focusing on what happens to people when they are imprisoned and the facilities provided for them in custody.

\section{The prison population in England and Wales}

Statistics on the prison population in England and Wales can be found on the websites of the Prison Service (http://www.hmprisonservice.gov.uk/ statistics/) and the Home Office (http://www. homeoffice.gov.uk/rds/prisons1.html).

The prison population grew steadily during the mid-1990s, from just over 44000 in 1993 to a peak of 66500 in mid-1998. It did not exceed this number until mid-2001. Since then, it has grown steadily. In June 2002, it stood at 71200 (Home Office, 2002). Longer-term growth forecasts anticipate an average prison population of 76700 by 2008 , but it could rise to as high as 83500 (Home Office, 2001).

Turnover in the prison population is considerable: around 140000 people pass through English and Welsh prisons each year (Department of Health, 2001).

Table 1 provides details of the prison population according to type of prisoner and gender. Although there are far fewer women than men in prison, the proportion of female to male prisoners has been increasing in recent years. Most prisoners are young,
Table 1 The prison population on 30 June 2002 by type of prisoner and gender (Home Office, 2001)

$\begin{array}{lrrr}\text { Type of prisoner } & \text { Male } & \text { Female } & \text { Total } \\ \text { Young prisoners }^{1} & 10950 & 660 & 11610 \\ \text { Remand } & 2520 & 167 & 2687 \\ \text { Sentenced } & 8370 & 480 & 8850 \\ \text { Non-criminal } & 58 & 6 & 64 \\ \text { Adults } & 55870 & 3740 & 59610 \\ \text { Remand } & 9560 & 830 & 10390 \\ \text { Sentenced } & 45600 & 2850 & 48450 \\ \text { Non-criminal } & 720 & 51 & 770 \\ \text { All remand } & 12080 & 1000 & 13080 \\ \text { All sentenced } & 53970 & 3340 & 57310 \\ \text { All non-criminal } & 770 & 57 & 830 \\ \text { Total }^{2} & 66820 & 4390 & 71220\end{array}$

1. Young prisoners include all those aged 15-20 years plus some 21 -year-olds aged 20 on conviction who have not been reclassified as adults.

2. Components may not sum, because of rounding.

Caucasian men. The majority are either remanded or sentenced in connection with offences involving violence against the person, burglary, theft or drugs.

Prisoners are particularly vulnerable to developing mental health problems. Histories of abuse, deprivation, homelessness, unemployment and substance misuse are common. Many prisoners have numeracy and literacy problems and most prisoners have a lower than average IQ (Her Majesty's Inspectorate of Prisons, 1997b, 2000a; Singleton et al, 1998).

It is also important to bear in mind that people with mental disorders are particularly vulnerable to imprisonment, and initiatives aimed at diverting them from custody are not always effective (Birmingham, 2001). Research suggests that, excluding substance misuse diagnoses, about onequarter of men entering prison on remand have some form of mental disorder (Birmingham et al, 1996).

\section{Psychiatric morbidity in prisons The prevalence of mental disorder}

Reports highlighting the problems caused by prisoners with mental illnesses are not a new phenomenon (Howard, 1780), but the first reliable estimates of the prevalence of psychiatric morbidity among prisoners in England and Wales were provided by two large-scale point-prevalence studies carried out in the late 1980s and early 1990s by the Institute of Psychiatry, London. These two surveys used data collected by independent psychiatric researchers, who interviewed samples of sentenced (Gunn et al, 1991) and remand (Maden et al, 1995) prisoners. The findings are summarised in Table 2. Mental disorder (including substance misuse 
Table 2 The frequency of psychiatric diagnoses in sentenced (Gunn et al, 1991) and remand (Maden et al, 1995) prisoners $^{1}$

\begin{tabular}{lcccccc} 
& \multicolumn{3}{c}{ Sentenced, \% } & \multicolumn{3}{c}{ Remand, \% } \\
ICD-10 diagnosis & Adult men & Male youths & Women & Adult men & Male youths & Women \\
Psychoses & 2.4 & 0.2 & 1.1 & 5.9 & 1.9 & 4.5 \\
Neuroses & 5.8 & 5.7 & 15.4 & 28.1 & 18.9 & 43.7 \\
Personality disorder & 8.8 & 14.1 & 16.1 & 11.0 & 11.7 & 15.5 \\
Substance abuse/dependence & 22.7 & 18.6 & 30.8 & 39.0 & 36.4 & 41.6 \\
Organic disorders & 1.0 & 0.5 & 2.6 & 0.7 & 1.5 & 1.6 \\
No diagnosis & 60.4 & 66.8 & 44.0 & 34.2 & 46.6 & 22.9 \\
1. Totals exceeds 100\% because some subjects have multiple diagnoses. & & &
\end{tabular}

diagnoses) was found in $37 \%$ of sentenced male prisoners, $63 \%$ of men on remand, $57 \%$ of sentenced women prisoners and $76 \%$ of women remand prisoners. Multiple diagnoses were commonly encountered, especially in remand prisoners: about one-quarter of men and one-third of women on remand received two or more diagnoses.

To inform policy decisions about services, the Department of Health commissioned a study from the Office for National Statistics (the ONS prison survey) in 1997 to provide up-to-date information about psychiatric morbidity among male and female remand and sentenced prisoners (Singleton et al, 1998). This large-scale survey (a point-prevalence study), which included prisoners from all prison establishments in England and Wales, used the same methods employed in the household survey of psychiatric morbidity in the general population (Meltzer et al, 1995). The findings of the survey are summarised in Table 3. The prevalence of mental disorder (in all forms) in prisoners surveyed was found to be considerably higher than that found in the general population (Meltzer et al, 1995).

The most prevalent personality disorder diagnosis in each of the four prisoner sub-groups was

Table 3 Findings of the 1997 ONS prison survey of psychiatric morbidity among prisoners in England and Wales (Singleton et al, 1998)

ICD-10 Men, \% Women, \%

Diagnosis Sentenced Remand Sentenced Remand Total

$\begin{array}{lccccc}\begin{array}{l}\text { Psychotic } \\ \text { disorder }\end{array} & 7 & 10 & - & - & 14 \\ \begin{array}{l}\text { Neurotic } \\ \text { disorder }\end{array} & 40 & 59 & 63 & 76 & - \\ \begin{array}{l}\text { Personality } \\ \text { disorder }\end{array} & 64 & 78 & - & - & 50 \\ \begin{array}{l}\text { Hazardous } \\ \text { drinking }\end{array} & 63 & 58 & 39 & 36 & - \\ \begin{array}{l}\text { Drug } \\ \text { dependence }\end{array} & 43 & 51 & 41 & 54 & -\end{array}$

1. Hazardous use in the year prior to imprisonment.

2. Current dependence.
DSM-IV antisocial personality disorder (American Psychiatric Association, 1994); in men, the second most frequently encountered category was paranoid personality disorder and, in women, it was borderline personality disorder. The highest rates of personality disorder were found among younger prisoners.

Rates of functional psychotic disorder (in the year prior to interview) were considerably higher than the overall prevalence of $0.4 \%$ reported in the general household survey of adults (Meltzer et al, 1995). Schizophrenia and delusional disorder were found more frequently than affective disorders.

The most frequently encountered neurotic symptoms among prisoners were sleep problems, worry, fatigue, depression and irritability. Women were more likely than men to report neurotic symptoms and remand prisoners of either gender reported neurotic symptoms more frequently than their counterparts who had been sentenced. The lowest rates of neurosis were found among prisoners held in open conditions.

The three prison surveys referred to above also collected data about drug and alcohol use. Although this article is not primarily concerned with substance misuse among prisoners, it is important to acknowledge both the effect that it can have on mental health and the extent to which prisoners use drugs and alcohol before and during imprisonment (Her Majesty's Inspectorate of Prisons, 1997a,b, 2000a). Table 3 shows the levels of hazardous alcohol use in the year prior to imprisonment and current drug dependence found during the ONS prison survey (Singleton et al, 1998). According to this survey, the drugs most frequently used in prison are cannabis and heroin; one-quarter of subjects gave a history of injecting drugs and a similar proportion of these said that they had accidentally overdosed on drugs at some point. Co-occurrence of mental disorder and substance misuse was common; more than threequarters of prisoners found to be dependent on drugs and marginally fewer of those assessed as 'hazardous drinkers' had two or more additional mental disorders. 


\section{Psychiatric treatment needs}

The point-prevalence studies conducted by the Institute of Psychiatry (Gunn et al, 1991; Maden et al, 1995) reveal a significant level of unmet mental health treatment needs among prisoners, especially those held on remand (Tables 4 and 5). The results relating to male prisoners suggest that, at the time these surveys were conducted, the prison population held in excess of 1000 men with psychosis and nearly 2000 male prisoners in need of immediate transfer to psychiatric hospitals for treatment.

The ONS prison survey (Singleton et al, 1998) did not directly address the issue of treatment, but the data collected do provide some indication of the level of need. Of those surveyed, $18 \%$ of male sentenced inmates, $21 \%$ of male remand prisoners and $40 \%$ of both remand and sentenced women prisoners said that they had received help for mental or emotional problems in the year prior to coming into prison. Of the female remand prisoners, $22 \%$ said that they had been admitted to a psychiatric hospital at some point in their lives, including $6 \%$ who were in-patients for at least 6 months and 11\% who had been admitted to a locked ward.

\section{Suicide and non-fatal self-harm}

The suicide rate in prison more than doubled between 1982 and 1998, from 54 to 128 per 100000 of the average annual prison population. Selfinflicted deaths currently represent about half of all deaths in prison and local prisons bear the brunt of prison suicides. The majority of self-inflicted deaths occur by hanging, and more than half occur during the first 3 months of imprisonment. Remand prisoners, young offenders, and those with a history of substance misuse and violent offences are at particular risk (Her Majesty's Inspectorate of Prisons, 1997b, 1999a).

A very high proportion of those interviewed during the 1997 national prison survey (Singleton et al, 1998) said that at some point they had

Table 4 Psychiatric treatment needs of sentenced prisoners (Gunn et al, 1991)

$\begin{array}{lccc}\text { Ideal treatment } & \begin{array}{c}\text { Adult men } \\ (\%)\end{array} & \begin{array}{c}\text { Male youths } \\ (\%)\end{array} & \begin{array}{c}\text { Women } \\ (\%)\end{array} \\ \begin{array}{l}\text { Prison care } \\ \text { Therapeutic } \\ \text { community }\end{array} & 10.3 & 9.4 & 22.0 \\ \begin{array}{l}\text { NHS in-patient } \\ \text { hospital care }\end{array} & 5.8 & 4.0 & 7.3 \\ \begin{array}{l}\text { Further } \\ \text { assessment }\end{array} & 3.5 & 1.0 & 4.0 \\ \text { None } & 5.0 & 5.7 & 9.5 \\ & 75.3 & 80.0 & 57.1\end{array}$

Table 5 Psychiatric treatment needs of remand prisoners (Maden et al, 1995)

\begin{tabular}{|c|c|c|c|}
\hline Ideal treatment & $\begin{array}{l}\text { Adult men } \\
\quad(\%)\end{array}$ & $\begin{array}{c}\text { Male youths } \\
\text { (\%) }\end{array}$ & $\begin{array}{c}\text { Women } \\
(\%)\end{array}$ \\
\hline Monitor & 2.0 & 1.5 & 2.0 \\
\hline Out-patient & 13.4 & 14.1 & 27.3 \\
\hline $\begin{array}{l}\text { Motivational } \\
\text { interviewing }\end{array}$ & 16.5 & 12.1 & 9.4 \\
\hline $\begin{array}{l}\text { Prison health care } \\
\text { centre }\end{array}$ & 2.6 & 0.5 & 2.9 \\
\hline $\begin{array}{l}\text { NHS in-patient } \\
\text { hospital care }\end{array}$ & 10.7 & 2.9 & 13.1 \\
\hline $\begin{array}{l}\text { Therapeutic } \\
\text { community }\end{array}$ & 15.1 & 0.7 & 13.9 \\
\hline No treatment & 5.5 & 11.7 & 8.6 \\
\hline No diagnosis & 34.2 & 46.6 & 22.9 \\
\hline
\end{tabular}

considered committing suicide. For example, $46 \%$ of male remand prisoners had thought of suicide in their lifetime, 35\% had had such thoughts in the past year and $12 \%$ had experienced suicidal thoughts in the week prior to interview. The rates for female remand prisoners were even higher. Suicide attempts were also common and, compared with their sentenced counterparts, prisoners on remand were more likely to report having made attempts on their life: $27 \%$ of male and $44 \%$ of female remand prisoners said that they had tried to commit suicide during their lifetime; $15 \%$ and $27 \%$, respectively, said that they had attempted suicide in the past year.

\section{Imprisonment and mental health}

\section{Prison establishments}

There are 138 prisons and related institutions in England and Wales. The details of each institution can be found on the Prison Service website (http:// www. hmprisonservice.gov.uk/prisons). Differences in design, capacity, function, facilities, population, culture and location mean that no two prisons are alike. Many of the prisons in use today were originally built in the Victorian era or earlier. The Prison Service acknowledges that having to work in old, inefficient buildings, which were not designed for the purpose for which they are currently being used, imposes limitations on the operation of many prisons (Prison Service, 2000a).

Prisons are classified according to their function and the level of security they provide. There are 16 women-only prisons, 4 mixed prisons and 118 menonly establishments in England and Wales. Local prisons are busy establishments serving nearby courts; these prisons take mainly remand prisoners and those serving shorter sentences. Training prisons take those serving longer sentences. Open 
(security category D) prisons are the least secure, intermediate levels of security are offered in category $\mathrm{C}$ and $\mathrm{B}$ closed training prisons and there are eight high-security (category A) prisons.

\section{Prison rules and standards}

Prisons are primarily concerned with security (Prison Service, 2000a). This requirement creates a regime that is naturally restrictive, especially in category A and B prisons. Daily operations are governed by strict rules (Prison Service, 2000b). To improve performance and compliance at all levels in the service, the Prison Service recently introduced new standards. These are published online at http://www.hmprisonservice.gov.uk/library / dynpage.asp?Page $=74$. The 62 standards currently in place include guidelines on the provision of health services for prisoners and many other issues that have a bearing on the mental health of those detained in prison.

\section{Reception and induction}

On arrival, all new prisoners undergo reception and induction programmes designed to gather information about them and help them familiarise themselves with their new environment. Standard health screening procedures carried out at reception and induction have been found to be cursory and ineffective (Birmingham et al, 1997). At one prison, three-quarters of prisoners assessed at reception as having a mental disorder were subsequently found, in the health screen conducted by the prison health care staff and prison medical officers, to have no mental state abnormalities of any kind (Birmingham et al, 1996).

\section{Accommodation}

Most prisoners are housed in cells located in selfcontained accommodation units called wings in older prisons and houseblocks in modern establishments. The standard of accommodation varies considerably between establishments, but prisoners held in local prisons and remand centres endure some of the worst treatment and conditions found in the prison system (Her Majesty's Inspectorate of Prisons, 2000a).

In the face of cutbacks and staff shortages, most prisons consistently run at or near maximum capacity. Prisons have little control over their intake, and problems can arise on days when large numbers of new receptions are received. Under such circumstances, it may be necessary to use whatever accommodation is available: in some prisons, the admission of new remand prisoners to health care centres owing to lack of space elsewhere is a regular occurrence. This can disrupt the routine in the health care section, reduce the time staff spend with patients and unsettle mentally disordered offenders held there.

\section{Activities and time spent unlocked}

The Prison Rules (Prison Service, 2000b) set out the requirements for physical education, time in the open air, work and education. The range of activities available to prisoners and the ease with which these can be accessed are determined by a number of factors. A major hindrance in this respect is lack of resources, especially ever-decreasing budgets and high levels of staff sickness. Prison culture and staff attitudes are also important. There are motivated, altruistic members of staff who are able create opportunities for prisoners with what little resources they have. However, the Prison Service is not short of staff who have less-positive attitudes towards those in their care, including some who wilfully neglect the prisoners' basic needs (Her Majesty's Inspectorate of Prisons, 2000b).

Those in local prisons and remand centres tend to suffer the worst treatment and conditions. The Chief Inspector of Prisons has made the observation that life in these establishments is dominated by the need to find space for prisoners rather than doing anything constructive with, and for, them (Her Majesty's Inspectorate of Prisons, 2000a). As a result, it is not uncommon for prisoners to have to idle away more than 20 hours and sometimes as much as 23 hours a day, locked in their cells. According to Singleton et al (1998), prisoners who are male, on remand and experiencing psychotic episodes are likely to be locked up for longer than other inmates. The level of confinement and isolation experienced by some prisoners is, in itself, detrimental to their mental health, but the situation is made worse by the fact that some prisoners turn to using illicit substances to help them deal with long periods of time spent locked up. It is not difficult to imagine how prisoners with pre-existing psychiatric problems deteriorate and others who are vulnerable to developing mental health problems decompensate in these conditions.

\section{Contact with the outside world}

Prisoners may lead an institutional life behind bars, but this does not mean that what goes on in the outside world ceases to have an effect on their wellbeing - far from it. Women prisoners, in particular, worry about their family, especially their children. 
Up to two-thirds of women in prison are mothers and nearly half of all women who are sent to prison have a dependent child living with them when they are imprisoned. Less than one-quarter of women in this position have a current or ex-partner available to care for their children while they are in prison (Her Majesty's Inspectorate of Prisons, 1997a).

Being remanded into custody while awaiting trial can be a very stressful time. Those who find themselves in this position not only have to cope with prison life, but also have to deal with ongoing court proceedings and may face considerable uncertainty about their future. Being able to stay in touch with friends and family while in prison is important, whatever your circumstances. Because local prisons serve local courts and the older ones, in particular, tend to be situated in or near town or city centres, visiting is not usually too difficult. On the other hand, newer prisons tend to be located in more remote places which are less well-served by public transport; furthermore, category A prisons, with their tight security arrangements, are less visitorfriendly. Distance may also be a barrier to visits. Those serving longer sentences may start off at a local prison, but they are usually dispersed to a training prison and may be moved within the prison system several more times before they are released.

\section{Discrimination and bullying}

The behaviour of inmates towards each other and the culture that this creates can have a profound effect on the mental health of prisoners. Bullying is particularly prevalent in women's prisons and young offender institutions, and sex offenders, especially those who have offended against children (referred to as 'nonces' by other prisoners), are at particular risk of being victimised and assaulted. For this reason, sex offenders and certain other vulnerable prisoners are usually housed separately in vulnerable-prisoner wings or units. They tend to be moved when other prisoners are locked up and they have separate regimes to keep them segregated from other prisoners. Prisoners from ethnic minorities may experience racial abuse, and problems can arise if cultural or religious needs are overlooked by prison staff.

Prisoners with mental health problems are also prone to discrimination. The prejudice and ridicule levelled by prisoners and even prison officers at inmates with mental health disorders is illustrated by the use of pejorative terms such as 'being nutted off' or 'sent to Fraggle Rock' to refer to their transfer to the prison health care centre. It is not surprising, therefore, that prisoners with mental health problems who retain some insight are wary of talking about their difficulties. Previous personal experience of sub-standard prison health care, fear of being placed in unfurnished accommodation or having treatment forced on them and suspicion of health care staff, who are seen as part of the establishment, are additional reasons why some prisoners with mental health problems choose not to disclose information.

\section{Health care}

The Prison Health Service, with its workforce of around 300 doctors (a combination of prison medical officers and part-time doctors, most of whom are also general practitioners) supported by prison health care officers and NHS-trained nurses, still constitutes the backbone of health care in prisons. It is fair to say that NHS mental health services do not tend to go out of their way to involve themselves with people in prisons. Some diversion services incorporate remand liaison schemes, but regular psychiatric input into prisons is usually provided by visiting forensic psychiatrists. Few prisons receive what could be regarded as a proper multidisciplinary service.

Prison Service standard 22, which deals with the provision of health services for prisoners, promotes the notion of equivalence of care (Box 1). In reality, however, the quality of health care provided for mentally disordered offenders varies considerably between prisons. Reed found that few prisons he inspected provided health care broadly equivalent to NHS care: in many, health care was of low quality, some doctors were not adequately trained to do the work they faced, and some care failed to meet proper standards of ethics (Reed \& Lyne, 1997). A report published by the British Medical Association (2001) claims that, because the NHS is ignoring the health needs of prisoners and working conditions in prisons are so poor, large numbers of doctors and nurses are leaving the Prison Health Service.

Larger prisons with health care beds and 24-hour observation provide in-patient health care facilities for clusters of nearby prisons that lack these facilities. Because these health care centres tend to be located in category A and B prisons, in-patient care is associated with conditions of higher security and hence a more restrictive prison regime. Although still often referred to as hospitals by prison staff, inpatient prison health care centres are quite unlike any hospital in the NHS. They are designed and staffed to function as cottage hospitals and they are not recognised as hospitals for the purposes of the Mental Health Act. This means that prisoners who require hospital treatment for mental disorder need to be transferred to a suitably secure psychiatric hospital. However, pressure on secure psychiatric hospital beds means that, compared with the level of need, relatively few hospital transfers take place 
each year (Hotopf et al, 2000). As a result, prison health care centres across the country are overflowing with people with mental illness who are in need of urgent treatment in a psychiatric hospital.

It is also fair to say that the problem goes beyond a lack of available beds. Mentally disordered offenders are not popular as patients and they often fail to meet the criteria required for acceptance by community mental health teams. Mentally disordered offenders with dual diagnosis, which constitute the majority, are particularly vulnerable in this respect. They are often rejected by community or in-patient mental health teams because they have a comorbid substance misuse problem, and are turned away by substance misuse services because of their mental illness. Generally speaking, only prisoners with the most seriously psychotic condition are selected for admission to outside hospitals and, even then, they may face a long wait before a bed becomes available.

The current state of prison health care means that in-patients with mental disorder are liable to experience unacceptable restrictions and spend their days with little in the way of constructive activity (Reed \& Lyne, 2000). Indeed, it is not uncommon to find that mentally disordered offenders held in prison health care centres are provided with less access to association, exercise and other facilities than are prisoners housed on ordinary location. Such restrictive practices, often surpassed only by the segregation regime in place, do little to address the treatment and rehabilitation needs of these individuals. Furthermore, low staffing levels and procedures for opening cells out of hours mean that it can take over 10 minutes to gain access to a prisoner in the health care centre at night. For prisoners with mental illnesses who are experiencing suicidal thoughts, this situation is quite unacceptable.

Not all of the 1700 prison health care centre beds in England and Wales are occupied by prisoners with mental health problems. The levels of psychiatric morbidity identified by the ONS prison survey (Singleton et al, 1998) indicate that there are large numbers of people with serious mental disorders housed in cells on ordinary prison wings and houseblocks (ordinary or normal location). Because prison reception health screening is ineffective and health care for prisoners tends to be based in the health care centre, prisoners with mental disorder who are placed on ordinary prison location are liable to remain undetected. Indeed, research suggests that there are plenty of mentally disordered offenders on prison wings who are not identified as such and whose treatment needs therefore remain unmet (Birmingham et al, 1998; Birmingham, 1999).

The current reform of prison health care involves a move away from the traditional model, which focuses on the prison health care centre, towards developing more comprehensive mental health promotion and primary care services together with day care and wing-based treatments for prisoners with mental health problems (Department of Health, 2001).

\section{Segregation and close-supervision centres}

Segregation is sometimes used as a punishment for prisoners who infringe prison rules. Some highersecurity prisons also have close-supervision centres for the detention of inmates who are very disruptive and dangerous. Prison Service standard 55 (segregation units) requires that the use of segregation achieves the correct balance between the requirement to maintain order and discipline and the respect for dignity'. In reality, the best a prisoner can expect in segregation is a basic level of provision offering minimal comfort combined with a highly restrictive regime. Some of the worst segregation units provide conditions that are filthy and inhuman (Her Majesty's Inspectorate of Prisons, 1999b).

\section{Prisoners at risk of suicide and self-harm}

Liebling (1992) stresses the similarities rather than the differences between those who injure themselves and those who complete suicide in prison. She proposes three broad categories of prisoners who are at particular risk of suicide (Liebling, 1995). The largest group is that composed of young prisoners who have poor coping skills, including a history of deliberate self-harm and who are vulnerable to the impact of imprisonment. In prison, they become acutely distressed, and feelings of fear, isolation and helplessness may lead to a fatal act of self-harm. The second group of prisoners comprises those who are older (over 30 years of age), facing or embarking on a long sentence and who feel guilty or ashamed about their offence and hopeless about their future. The third group contains those with psychiatric illnesses, who are isolated and poorly equipped to cope.

The approach adopted in prison towards the management of people deemed to be at risk of selfharm is changing, and less emphasis is now placed on physical methods of prevention. The use of 'strip (unfurnished) cells' for this purpose was recently abolished, in recognition of the fact that such conditions are detrimental to mental health and probably represent a breach of human rights.

In recent years, more emphasis has been placed on screening and risk assessment, providing better training for prison staff, promoting suicide awareness and ensuring that care and support are available for prisoners at risk. Prisoners have also been encouraged to play an active role in suicide 
prevention by acting as 'buddies' (sharing a cell with a prisoner considered at risk of suicide) and training as 'listeners' (Prison Service \& NHS Executive, 1999).

In February 2001, the Prison Service announced a new 3-year proactive strategy to reduce suicide and self-harm in prisons (http://www.hmprisonservice. gov.uk/news/newstext.asp?200). This initiative includes proposals for physical improvements to reception and induction areas; the installation of more first-night support centres; and the creation of more safe cells, crisis suites and cells that enable staff to monitor at-risk prisoners. The revised riskbased suicide prevention strategy, which is overseen by a new 'safer-custody group', is initially being targeted at local prisons where most suicides occur (Prison Service, 2001).

\section{Conclusions}

Prisons are unremittingly grim places that provide conditions wholly unsuitable for those with severe mental disorders. Despite this, the prison system in England and Wales probably houses thousands of people with serious mental illness and many more with other forms of mental disorder. This no doubt reflects a number of facts: offenders are particularly vulnerable to developing mental health problems; people with mental disorders are vulnerable to imprisonment; imprisonment is detrimental to mental health; and relatively few prisoners with mental illness are transferred to hospital for treatment.

Conditions vary enormously from establishment to establishment, but many prisoners have to endure unpleasant conditions and abide by strict regimes. Discrimination and bullying, isolation from friends and family, and long periods spent in confinement can place a considerable strain on a remand prisoner who faces uncertainty about the future or a convicted prisoner who is looking forward to a lengthy sentence. Illicit drugs with the capacity to exacerbate or induce mental disorder are also widely available in prison. The prospects for mentally disordered offenders are particularly bleak: in the majority their mental illness remains undetected and untreated and, if they transgress the rules, they risk disciplinary action resulting in loss of privileges and possibly even a period in segregation.

The punishment of imprisonment is not restricted to the loss of liberty: it also includes the provision of second-class health care. Although the Prison Service has been repeatedly, and in some cases justifiably, criticised for this it cannot be blamed for the high prevalence of psychiatric morbidity in prisons. The NHS and social services must take responsibility for failings in hospital and community care which have resulted in the incarceration of people with mental disorders in prison. The NHS must also deal with its unwillingness to accept the transfer of such prisoners to NHS hospitals for treatment and its general reluctance to work in prisons, because its new partnership with the Prison Service means that it is now accountable to the prisoners.

It is reassuring that the Government has made a commitment in the NHS Plan to improving mental health services for prisoners (Department of Health, 2000). This includes 300 additional mental health staff by 2004, backed up with new money for psychiatric care in prisons. Over the next 3 years, there will also be $£ 35$ million of new money made available for getting prison health care centres up to scratch (http://www.doh.gov.uk/prisonhealth/ development.htm). Things are beginning to change in prisons: developments in suicide prevention are taking place; the reception health screening process is being reviewed; and, in some prisons, multidisciplinary working and the Care Programme Approach have been introduced. However, it will not be plain sailing. A British Medical Association report on prison medicine (British Medical Association, 2001), which warns of a crisis waiting to break, is concerning and some Government targets for prison health care are likely to be difficult, if not impossible to achieve. For example, is it really going to be possible to ensure that, by 2004, appropriate after-care will be provided for every person with mental illness who leaves prison (Department of Health, 2000) when the vast majority of such illness in prison at the moment is not even recognised? Sir David Ramsbotham, the former Chief Inspector of Prisons, is quite correct in his view that 'concerted and determined action is required to bring prison health care up to accepted standards' (BMJ, 2001).

\section{References}

American Psychiatric Association (1994) Diagnostic and Statistical Manual of Mental Disorders (4th edn) (DSM-IV). Washington, DC: APA.

Birmingham, L. (1999) Prison officers can recognise hidden psychiatric morbidity in prisoners. BMJ, 319, 853 .

- (2001) Diversion from custody. Advances in Psychiatric Treatment, 7, 198-207.

-, Mason, D. \& Grubin, D. (1996) Prevalence of mental disorder in remand prisoners: consecutive case study. $B M J$, 313, 1521-1524

—, _ \& — (1997) Health screening at first reception into prison. Journal of Forensic Psychiatry, 8, 435-439.

-, - \& - (1998) A follow-up study of mentally disordered men remanded to prison. Criminal Behaviour and Mental Health, 8, 202-213.

British Medical Association (2001) Prison Medicine: A Crisis Waiting to Break. London: British Medical Association.

$B M J$ (2001) NHS ignoring prisoners' health needs, says report (News roundup). 322, 1014.

Department of Health (2000) The NHS Plan: a Plan for Investment, a Plan for Reform. London: HMSO.

- (2001) Changing the Outlook. A Strategy for Developing and Modernising Mental Health Services in Prisons. London: Department of Health.

Gunn, J., Maden, A. \& Swinton, M. (1991) Mentally Disordered Prisoners. London: Home Office. 
Health Advisory Committee for the Prison Service (1997) The Provision of Mental Health Care in Prisons. London: Prison Service.

Her Majesty's Inspectorate of Prisons (1996) Patient or Prisoner? A New Strategy for Health Care in Prisons. London: Home Office.

- (1997a) Women in Prison: A Thematic Review by HM Chief Inspector of Prisons. London: Home Office.

- (1997b) Young Prisoners: A Thematic Review by HM Chief Inspector of Prisons for England and Wales. London: Home Office.

- (1999a) Suicide is Everyone's Concern: A Thematic Review by HM Chief Inspector of Prisons for England and Wales. London: Home Office.

- (1999b) HM Prison Wandsworth: Report of an Unannounced Short Inspection, 13-16 July 1999. London: Home Office.

- (2000a) Unjust Deserts: a Thematic Review by HM Chief Inspector of Prisons of the Treatment and Conditions for Unsentenced Prisoners in England and Wales. London: Home Office.

- (2000b) Annual Report of HM Chief Inspector of Prisons for England and Wales, 1998-1999. London: Home Office

Home Office (2001) Projections of Long Term Trends in the Prison Population to 2008. London: Home Office.

- (2002) Prison Population Brief, England and Wales: June 2002. London: Home Office.

Hotopf, M., Wall, S., Buchanan, A., et al (2000) Changing patterns in the use of the Mental Health Act 1983 in England, 1984-1996. British Journal of Psychiatry, 176, 479-484.

Howard, J. (1780) The State of the Prisons in England and Wales (2nd edn). Warrington and London: T. Cadell.

Liebling, A. (1992) Studies in Prison, London: Routledge.

- (1995) Vulnerability and prison suicide. British Journal of Criminology, 35, 173-187.

Maden, A., Taylor, C. J. A., Brooke, D., et al (1995) Mental Disorder in Remand Prisoners. London: Home Office.

Meltzer, H., Gill, B. \& Petticrew, M. (1995) The Prevalence of Psychiatric Morbidity Among Adults Aged 16-64, Living in Private Households in Great Britain. London: Office of Population, Censuses and Surveys.

Prison Service (2000a) Annual Report: 1999-2000. London: Home Office.

- (2000b) The Prison Rules 1999 (as Amended by the Prison (Amendment) Rules 2000 and the Prison (Amendment) (No.

2) Rules 2000) (Statutory Instruments, no. 728). London: Home Office.

- (2001) Prevention of Suicide and Self-harm in the Prison Service. An Internal Review. London: Home Office.

Prison Service \& NHS Executive (1999) Suicide in Prisons: Research, Policy and Practice. Brighton: Pavilion Publishing.

Prison Service \& NHS Executive Working Group (1999) The Future Organisation of Prison Health Care. London: Department of Health.

Reed, J. \& Lyne, M. (1997) The quality of health care in prison: results of a year's programme of semi-structured inspections. $B M J, 315,1420-1424$.

_ \& - (2000) Inpatient care of mentally ill people in prison: results of a year's programme of semi-structured inspections. $B M J, 320,1031-1034$.

Singleton, N., Meltzer, H. \& Gatward, R. (1998) Psychiatric Morbidity among Prisoners in England and Wales (Office for National Statistics). London: Stationery Office.

Smith, R. (1999) Prisoners: an end to second class health care? BMJ, 318, 954-955.

\section{Multiple choice questions}

1 Regarding women prisoners:

a there are four women-only prisons in England and Wales

b bullying is generally more common in women's prisons than in prisons holding adult men

c female prisoners have higher rates of psychosis than do male prisoners d nearly half of all women sent to prison have a dependent child living with them when they are imprisoned

e the 1997 ONS prison survey reports that the prevalence of neurotic disorder among women on remand was in excess of $75 \%$.

2 More than 1 in 20 prisoners on remand in England and Wales:

a suffer from psychosis

b have an IQ score below 80

c are homeless or living at a temporary address before imprisonment

$\mathrm{d}$ are women

e interviewed during the 1997 ONS prison survey had contemplated suicide in the week prior to interview.

3 Mentally disordered offenders:

a are likely to spend more time locked in their cells each day than are other prisoners

b are usually recognised as such either at reception into prison or during the course of imprisonment

c who satisfy criteria for detention under the Mental Health Act 1983 can be detained and treated in a prison health care centre

d may be in prison because the court has specifically chosen to remand them there in order to obtain a medical report on their mental condition

e are no more or less likely to have a history of deliberate self-harm than are other offenders.

4 Suicides in prison:

a currently account for about half of all deaths in prison

$\mathrm{b}$ are much more likely to be associated with hanging than with any other method

c occur more frequently in local prisons than in other prisons

d are less frequent now than in the early 1980s, owing to changes in the approach to the management of suicidal prisoners

e usually take place within the first 3 weeks of imprisonment.

5 Prison health care centres:

a are found in every prison

b provide about 1700 in-patient beds throughout the prison system in England and Wales

c are the focus of current reform of prison health care

$\mathrm{d}$ often have a more restrictive regime than that found on the prison wing

e have the vast majority of their beds occupied by mentally disordered offenders.

\section{MCQ answers}

\begin{tabular}{|c|c|c|c|c|}
\hline & 2 & 3 & 4 & 5 \\
\hline $\mathrm{F}$ & a $\mathrm{T}$ & a $\mathrm{T}$ & a $\mathrm{T}$ & a F \\
\hline $\mathrm{T}$ & $\mathrm{b} \mathrm{T}$ & $b F$ & b $\mathrm{T}$ & $\mathrm{b} T$ \\
\hline $\mathrm{T}$ & c $\mathrm{T}$ & c F & c $\mathrm{T}$ & \\
\hline $\mathrm{T}$ & $\mathrm{d} T$ & $\mathrm{~d} T$ & d F & d \\
\hline $\mathrm{T}$ & e $\mathrm{T}$ & e F & e $\mathrm{F}$ & e \\
\hline
\end{tabular}

